\title{
Creative peculiarities of drama pieces in the Karakalpak literature of the 20th century (On the basis of T.Qayipbergenov's dramatical pieces)
}

\author{
M.Palymbetova ${ }^{1}$ \\ ${ }^{1}$ Doctoral student, Karakalpak State University named after Berdakh, Uzbekistan
}

\begin{abstract}
The article is devoted to identifying the genre features of the works of the prose writer and playwright $\mathrm{T}$. Kaipbergenov. In the article we focused on the history of the drama in the Karakalpak literature of the twentieth century and the study of its development history by scientists. We also noted that the drama in the Karakalpak literature originated in the 20s of the twentieth century, and the very first playwrights were K.Auezov, S.Mazhitov, A.Otepov and reviewed their dramatic works. We considered the features of the study and the objects of study of such researchers as K. Ayymbetov, T. Allanazarov, T. Bayandiyev, K. Sultanov, and in the years of independence K. Kamalov, S. Allayarov, K. Kurambaev, J. Esenov, O Satbayev, B.Tursinov, I.Oteuliyev, Zharimbetov and others.

The prominent figure in Karakalpak literature, T. Kaipbergenov, as a publicist, prose writer and playwright, made a great contribution to the 20th century Karakalpak literature, becoming famous for his works all over the world. He played a major role in the comprehensive development of our literature, writing, along with prose works, such dramatic works as "Last Name", "Aidos Baba", and "Sakhra Bulbuli". Therefore, this article is devoted to the study of ideas and themes, genre features and the system of images of these works, who have made a great contribution to the development of Karakalpak literature.
\end{abstract}

Keywords: funny words, skill, act, kind, image, drama, character, tragedy, comedy, historical fact, novel, poem, conflict, culmination, transformation, dastan, genre.

\section{INTRODUCTION}

After the Republic of Uzbekistan was declared independent karakalpak playwrights having been inspired by the independence, found their appropriate ways of development, created and are creating stage plays keeping up their national creative traditions as well. Representing the historical theme and the foretime and folk-ethnographic motives played a great role in the karakalpak drama of the independence period. For instance, we can see that our playwrights tried hard to create such characters as Aydos Baba, ErnazarAlakoz, Berdakh, Ajiniyazand so on. On this basis, we considered it to be relevant to study the degree how drama pieces, created during the independence, measure up the requirements of the time, what are the genres of the works, the creativity of the writer in representing the historical figures and events.

The research on the Karakalpak dramaturgy had been carried out since 1950-1960. First of all, Q.Ayimbetovwrote his dissertation on "The essays of the karakalpak dramaturgy" and, on this basis, his work "The essays from the history of the karakalpak soviet dramaturgy" was published. [1] Thereafter, T.Allanazarov'smonographies, the books and articles of M.Daribayev, B.Tursinov, Q.Sultanov, A.Nasurullayev, J.Boleshova, A.Jarimbetov, F.Utemuratov, A.Seytbekov, R.Matmuratova, M.Mambetova [2] became the issues of the karakalpak dramaturgy.

The research activities and theoritical ideas of drama reaserchers and such Russian scholars as V.V.Frolov, N.N.Chistyukhin, Uzbek researchers as K.Kayumov, B. Imamov, H.Abdusamatov, kazakh researchers as A. Tajibayev, R. Nurgaliyev, S. Ordaliyev, karakalpak scientists as Q. Ayimbetov, T. Allanazarov, B. Tursinov played a great role as methodological data.

On our research work we used comparative-historic, esthetic analyzing and structural methods.

The hero of the Republic of Uzbekistan, the folk writer of Uzbekistan and KarakalpakstanTolepbergenQayipbergenov made a great contribution to the karakalpak literature of the $20^{\text {th }}$ century as an outstanding novelist, playwright and publicist. He made an influence to the development of our literature with his such drama pieces as "Familiya", "Aydos Baba", "Sahrabulbili" 
("The desert nightingale") and so on. His characters as Aydos Baba, ErnazarAlakoz, Berdakh have been highly estimated by our writers.

The aim of T.Qayipbergenov's work "Familiya" [3] ("Surname") was to illustrate the truth of the repression period. We can see in the drama that the problem of the bad ailments of that period is highly arisen.

"The value of the drama is in the fact that it found the solution to these problems in connection with the issues of comportment and spiritual riches in the writer's interviews, speech, literary talks and articles." [4]

The writer managed to reflect the temper, psychology and thoughts of the characters through those characters' words, monologues, dialogues. The quality of the love for fame is given through the character ofTemirAytenov. It can be noticed that these ideas in the novel "Kozdinqarashigi" which illustrated the truth of the repressionperiod is represented in "Familiya" more deeply.

We can also come across with such drama pieces in the karakalpak dramaturgy of $20^{\text {th }}$ century which had taken the historical events as the basis and the historical figures as prototypes. Some of them are the dramas of original plot while others are the ones turned to drama through the transformation of the plots of other genres. For example, the drama "Amudaryaboyinda" ("On the bank of Amudarya") created on the basis of J.Aymurzayev's novel " Amudaryaboyinda”, G.Abdulov and T.Bayandiyev's drama "Qaraqalpaqqizi" ("The daughter of karakalpaks") (1967) on the basis of T.Qayipbergenov's novel "Qaraqalpaqqizi", the drama "Jumagul” (1974), S.Hojaniyazov's drama “ Adalatqaqiyanet" ( "The treason to justice") on the basis of Berdakh's epic poem "Aqmaqpatsha" (" The foolish king"), the tragedy "AydosBaba" [5] created on the basis of T.Qayipbergenov'snovel "Baxitsizlar" ("Wretches"), T.Allanarov'stragedy "Aydos Baba" [6] created on the basis of the mentioned above novel, A.Utaliyev's tragedy "Yernazaralakoz" [7] are worth of mention.

Such transformation of works requires a great intelligence and creative skills from the playwright. If we investigate T.Qayipbergenov's "Aydos Baba" [8] ("Min tillage bahalangangelle") [5]created on the basis of "Baxitsizlar" ("Wretches") we see that it measures up the requirements of drama. The novel is in 23 publications and it tells the story of the events since 1806. The novel has numerous characters and they are enriched with historical figures too. If some plots in the novel are used without any changes, others are given as a remark to the tragedy. While the novel starts with the explanation of Dospan's looking after the cattle and the reasons why Aydos leaves for Khiva, the tragedy begins with the appearance of Aydos Baba and Dospan.Furthermore, the chapter of Aydos Baba's speech in front of the khan about the origin of races, Mamanbiy's being taken by Russian Empire and Aydos Baba's usage of rational sayings from "Quran", "Hadis" in the tragedy is absent in the novel. This is considered to be the author's own plot for the new genre. The compositional structure of the drama involves 4 acts, 19 scenes. The number of the participants is 11-12. The basic events take place around Aydos Baba. The author did not add extra characters as it is not easy to transfer a large amount of events from the novel into the drama and introduce it with few characters.

This tragedy tells the story of karakalpaks' fighting against the deals of Khiva Khan around 18101827. The real plot of the tragedy involves the fighting of karakalpaks for the establishment of "The Independent Karakalpak Khanate". In this way Aydos Baba does not retract anything. He even does not forgive his brothers. However, because of his brothers' protest and people's disbelief all his efforts end up unsuccessfully. This struggle for freedom which remained sad in the karakalpak history ends up with the hero's death.

In order to fully illustrate the characters of Aydos Baba, Begis, Mirjiq, khans of Khiva, the author wisely picked up the historical events, especially the moments full of conflicts and dramatic effects and made the them the foundation of the novel and the drama. In this case, we can notice T.Qayipbergenov's literary skills and his knowledge awareness of the drama theory.

In the past those who used to make the political agreement with the khan of Khiva were retributed both in life and literary essays. In the tragedy "Aydos Baba" T.Qayipbergenov created the character of AydosBiy in the new outlook. AydosBiy is presented in the character of a hero who carries about his people, his nation, their freedom and solidarity. For example: ...My main purpose is to unite all the karakalpaks. 
...Even if I were made to believe that my nation would gain freedom but if I were hanged then, I would cry out that my death was the happiest one. [5]

This played a great role in creating a figure "Aydosbaba". As in karakalpak literature such figure like Aydosbabacan not be found in literature of previous times. So T.Qayipbergenov by observing historical events, facts, great names of history, created figures in literature of great historical characters.

In that way, T.Qayipbergenov's tragedy "Aydosbaba" is created in traditionally compositional method. In this work new authorial thoughts and ideas about historical characterAydos are given. In the case when last achievements of the scene and review of this play are taken into consideration, and the play is presented to the audience it would find its price and level.

T.Qayipbergenov's other drama work, which was published in the classic journal of 19th century "Amudarya" and which helped to understand our history is "Desert's nightingale"(Berdaqtin hasireti) [8]Compositional drama consists of 3 acts. In this drama Berdakh's life from 20-21 till 65-70 years is depicted. This play is opened by such characters like Berdakh, his wife, daughter Hurliman, Ajiniyaz, ErnazarAlakoz, khan of Khiva, merchants, the rich, hakeems, fisherman, farmers, cattlemen and others. Drama begins with the episode of Berdakh's narration to people about his six-months travel, the sacred buildings that he had visited. Berdakh visited graves of great ancestors such as Ahmad Yassaviy, NajmiddinKubro. Futhermore, he also have been to Tashkent, Samarkand, Bukhara, Khiva, Old Urgench.

In the play, both ErnazarAlakoz and Ernazarbiy are described as very friendly with each other, they work and think what to do jointly. ErnazarAlakoz, like Amir Timur made Samarkand the capital of the country, wanted to make Bozataw as a capital. Ernazarbiy brought architects from Khiva and Bukhara to Berdakh. Bozataw became capital after the establisment of theKarakalpak khanate. Khanate needed more educated people, that's why madrasahs and libraries were enlarged. Karakalpak people did it in order to create Karakalpak khanate. However, happy days did not last long.

One of karakalpak heroes who coud bring indepence to the country died.

Someone (Ernazar Alakoz praised him to Berdakh) who served in the same way as Yernazar Alakoz's assistant went round him and stabbed his shoulder blade with a knife [8].

So in that way, karakalpak people lost hero who wanted his country become independent. Ajiniyaz, Berdakh and all people were heartsore. Soon Berdakh's daughter Hurliman was born. He brought up and educated her. Berdakh sent her to Khiva where she started her education. Thenshebecameapoetlikeherfather.

\section{CONCLUSION}

T.Qayipbergenov's play"Sahrabulbili"consists of 3 acts. This work meets requirements of the drama genre. All in all there are 46 pages. The number of main characters is 6 , and there are 14 minor characters.

"Sahrabulbili" is well written according to drama genre requirements. Appropriate to its title there are chapters describing Berdakh's life and his works. Although some episodes are far from reality, but well structured from the creative point of view. For example, let's observe Berdakh's travel to Tashkent, Samarkand, Bukhara, Turkistan and Khiva. By this author wanted to show that Berdakh is curious and in the way for education, knowledge and spirituality he is ready for everything.

Taking everything into consideration, the meanings of T.Qayipbergenov's works "Familiya","Aydosbaba", "Sahrabulbili"are aimed to illustrate the repression period, historical movements for freedom and historical figures. These kinds of works are important in bringing up future generations, awakening love to their motherland. However, such plays were not staged before.

If T.Qayipbergenov's works are looked through thoroughly from modern theatrical point of view and are presented to the audience, plays would find their price and level.

\section{REFERENCES}

1. Ayimbetov K."Qaraqalpaq Sovet dramaturgiyasinin' tariyxinan ocherkler"("Historical essays from the Karakalpak Soviet dramaturgy"), Nukus city, Karakalpakstan, 1963.

2. QayipbergenovT. "Familiya" (drama, publicism). - Nukus, Karakalpakstan, 1988 
3. Nurjanov P, Jarimbetov A. "T.Qayipbergenov's drama"Familiya"(Pharaoh. Kheops pyramid) and its peculiarities".// The informer of The Department of The Academy of Sciences of The Republic of Uzbekistan in Karakalpakstan, №5-6, 2004

4. Qayipbergenov T. "AydosBaba"(Mintillagebahalangangelle). // Erkin Karakalpakstan. №22$27,1998$.

5. Allanazarov T. "Aydos Baba"Nukus, Karakalpakstan, 1992

6. Utaliyev A. "ErnazarAlakoz"Nukus, Karakalpakstan, 1997

7. Qayipbergenov T. "Sahrabulbili" (Berdaqtin hasireti). // Amiwdarya, №3-4, 1997. 